ANUVA Volume 2 (1): 19-27, 2018

Copyright (C2018, ISSN: 2598-3040 online

Available Online at: http://ejournal.undip.ac.id/index.php/anuva

\title{
Pelestarian Kesenian Tradisional sebagai Upaya Dalam Menumbuhkan Kecintaan Budaya Lokal di Masyarakat J urang Blimbing Tembalang
}

\author{
Ana Irhandayaningsih $\left.{ }^{1 *}\right)$

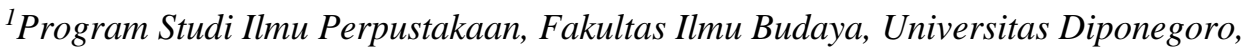 \\ Jl. Prof. Soedarto, SH, Kampus Undip Tembalang, Semarang, Indonesia \\ ${ }^{*)}$ Korespondensi: irhandayaningsih@gmail.com
}

\begin{abstract}
This article entitled Preservation of traditional arts as an effort in growing the love of Local Culture in the community Blossom Tembalang, explaining about various issues related to the preservation of traditional arts in the community Blossom Tembalang. There are several studies in this article that are: 1. Art as Local Identity, 2. Documentation as a Preservation, 3. Design of Art Preservation through Multimedia Packaging, 4. Implementation Process of Preservation Design, 5. Local Culture. In describing the discussion of this article the factors that hamper, among others, 1. The number of people teruama younger generation who are not familiar with traditional arts 2. Public awareness to preserve traditional arts is very less .. Jurang Blimbing Village Tembalang Village, Tembalang District, Semarang City is a Village thematic pioneered as one of Thematic Village of Art and Culture in Central Java area. With a variety of artistry in this village has more potential in improving the competitiveness of art and culture in Central Java. In this article the author tries to describe using descriptive research method. The author looks directly at the problems that are in place and see the importance of optimization of documentation as a supporter of preservation and encourage a sense of pride in the traditional arts of Thematic Village Art and Culture Village Blowing Blimbing. Then the author develops the specific problems that exist in place and make the Design Innovation in the form of implementation
\end{abstract}

Keywords:, preservation, traditional art, local culture

\begin{abstract}
Abstrak
Artikel ini berjudul Pelestarian kesenian tradisional sebagai upaya dalam menumbuhkan kecintaan Budaya Lokal di masyarakat Jurang Blimbing Tembalang, memaparkan tentang berbagai permasalahan terkait dengan Pelestarian kesenian tradisional di masyarakat Jurang Blimbing Tembalang. Ada beberapa kajian dalam artikel ini yaitu : 1 . Seni Sebagai Identitas Lokal, 2. Dokumentasi sebagai wadah Pelestarian, 3. Rancangan Pelestarian Kesenian melalui Kemasan Multimedia, 4. Proses Implementasi Rancangan Pelestarian, 5. Budaya Lokal. Dalam menguraikan pembahasan artikel ini faktor-faktor yang menghambat antara lain 1. Banyaknya masyarakat teruama generasi mudanya yang sudah tidak mengenal kesenian tradisional 2. Kesadaran masyarakat untuk melestarika kesenian tradisonal sangat kurang.. Desa Jurang Blimbing Kelurahan Tembalang, Kecamatan Tembalang, Kota Semarang merupakan Desa tematik yang dirintis sebagai salah satu Desa Tematik Seni dan Budaya di daerah Jawa Tengah. Dengan beragam kesenian didalamnya desa ini memiliki potensi lebih dalam peningkatan daya saing kesenian dan kebudayaan di daerah Jawa Tengah. Dalam artikel ini Penulis mencoba memaparkan menggunakan metode penelitian deskriptif. Penulis melihat secara langsung permasalahan yang berada di tempat tersebut dan melihat pentingnya optimalisasi dokumentasi sebagai penunjang pelestarian serta mendorong rasa kebanggaan terhadap seni tradisional Desa Tematik Seni dan Budaya Desa Jurang Blimbing. Kemudian Penulis mengembangkan secara spesifik permasalahan yang ada di tempat dan membuat Rancangan Inovasi yang berupa pengimplementasian
\end{abstract}

Kata kunci :, pelestarian, kesenian tradisional, budaya lokal

\section{Pendahuluan}

Seni adalah suatu hal yang merujuk kepada keindahan (estetika). Menurut The Liang Gie (1997:17), keindahan atau indah adalah sebuah kata yang sepadan dengan kata beauty dalam bahasa Inggris (dalam bahasa Perancis "beau", bahasa Italia dan Spanyol, "bello"). Monroe Beardsley, ahli estetika modern di abad ke-20 menjelaskan bahwa terdapat tiga unsur yang menjadi sifat dasar membuat suatu yang 
baik dan indah dalam seni. Antara lain : Kesatuan (Unity), Kerumitan (Complexity),dan Kesungguhan (Intensity). Seni adalah suatu produk budaya dari sebuah peradaban manusia, sebuah wajah dari suatu kebudayaan yang diciptakan oleh suatu sekelompok masyarakat atau bangsa. Secara teoritis, seni atau kesenian dapat didefinisikan sebagai manifestasi budaya (priksa atau pikiran dan rasa; karsa atau kemauan; karya atau hasil perbuatan) manusia yang memenuhi syarat-syarat estetik (Anshari, 1986:116).

Kebudayaan berasal dari bahasa Sansekerta buddhayah, yang diartikan sebagai bentuk jamak dari konsep budhi dan dhaya (akal). Konsep ini, diterapkan oleh para tokoh pemikir kebudayaan dan pendidikan Indonesia Ki Hajar Dewantara dipakai untuk membangun konsep budaya asli milik Indonesia. Menurut Koentjaraningrat di dalam bukunya Pengantar Ilmu Antropologi (1979), muncul teori kebudayaan yang wujudnya dikemukakan oleh Talcott Parsons dan A.L. Kroeber yaitu wujud sistem ide-ide dan konsepkonsep, wujud rangkaian tindakan, dan wujud aktivitas berpola manusia. Selain itu peneliti J.J Honigmann isi buku The World of Man (1959, hlm 11-12) menyebutkan adanya tiga gejala kebudayaan, yaitu gejala ideas, activities, dan artifacts. Jika dirumuskan sebagai sesuatu yang berkaitan satu sama lain. Para ahli berkesimpulan bahwa ide-ide atau gagasan-gagasan terdapat di dalam pemikiran manusia. Tentunya sebagai hasil olah otak. Karena di otak alias kepala manusia maka ide-ide itu tidak tampak dan tidak terlihat. Hanya terdengar bila disebutkan secara oral oleh pemikirnya. Kemudian terlihat ide-ide itu bila dituliskan atau ditayangkan melalui media.

Pentingnya Seni dan Budaya didalam Masyarakat seringkali dijadikan hal yang dilupakan. Seni harus menciptakan kerinduan akan hidup yang abadi, karena tujuan utama dari seni adalah hidup itu sendiri. Seni dianggap sebagai saran yang penting bagi prestasi kehidupan sehingga ia harus memelihara ladang kehidupan agar tetap hijau dan memberikan petunjuk kehidupan bagi manusia. Seni memiliki daya magis dan harus dimanfaatkan untuk menciptakan pribadi manusia yang baik. seni harus mampu membuat kemajuan social. Seniman dapat dianggap sebagai orang agung dan menjadi panutan. Menurut Muhammad Iqbal, seorang seniman dengan kekuatan 'kenabian'-nya mampu meninggikan derajat suatu bangsa dan mengatarkannya ke arah kebesaran demi mencapai kebesaran yang lebih tinggi lagi sehingga mampu memuaskan batin seniman dalam berkarya seni. Selain itu mampu memuaskan batin orang lain. Dengan cara masyarakat penikmat karya seni para seniman pasti akan memiliki tingkatan penilaian terhadap karya seni para seniman. Mampu mengenang sejarah melalui seni berhubungan dengan edukasi yang bertujuan untuk menyalurkan pesan-pesan sejarah untuk dikenang oleh generasi berikutnya. Menyampaikan nilainilai budaya dan ekspresi seniman ini sangat penting untuk melestarikan seni budaya didalam masyarakat.

Kesenian dapat diekspresikan sebagaimana mestinya. Ragam kesenian bermunculan seiring perkembangan zaman. Salah satunya Kesenian tradisional yang memiliki bentuk bermacam-macam, ada yang menggabungkan antara tari dan musik, nyanyian dan musik dan lain sebagainya. Hal ini bisa dilihat seperti pada masyarakat yang tinggal di Desa Jurang Blimbing, Tembalang. Desa Jurang Blimbing 
mempunyai beberapa kesenian rakyat yang masih bertahan sampai sekarang, kesenian tersebut diantaranya yaitu kesenian kethoprak, kuda lumping, kaligrafi dan rebana.

Tantangan dalam upaya pelestarian kebudayaan khususnya kesenian tradisional tersebut semakin berat karena berkembangnya zaman serta adanya arus globalisasi pada masa sekarang ini. Perkembangan zaman serta adanya arus globalisasi ini mengakibatkan banyak perubahan-perubahan yang terjadi di dalam pola kehidupan masyarakat, yang juga berpengaruh pada kebudayaan masyarakat itu sendiri. Kebudayaan daerah peninggalan leluhur sudah mulai terpengaruh dengan kebudayaan-kebudayaan yang berasal dari luar dan lambat laun kebudayaan daerah tersebut mulai ditinggalkan. Kebudayaan daerah di Indonesia ada yang murni hasil dari karya, cipta masyarakat

Indonesia sendiri dan ada yang terpengaruh dengan kebudayaan asing karena adanya komunikasi dengan kebudayaan asing pada masa lampau. Kebudayaan daerah khususnya kesenian-kesenian tradisional pada masa sekarang ini sudah mulai terpinggirkan dan digantikan oleh kesenian yang lebih modern. Masyarakat sudah mulai terbuka dengan perkembangan yang ada karena terjadi perubahan sosial pada masyarakat, keterbukaan terhadap kebudayaan luar, serta adanya modernisasi dan globalisasi yang secara tidak sadar merubah kebudayaan-kebudayaan yang ada pada masyarakat.

Desa Tematik Jurang Blimbing merupakan desa yang memiliki potensi kesenian yang variatif. Namun, dalam perjalanan banyak perubahan yang terjadi karena beberapa faktor yang mempengaruhi. Faktor terbesar menurut sebagian masyarakat adalah adanya Relokasi Universitas Diponegoro ke Daerah Tembalang. Dalam Perkembangannya desa tematik seni dan budaya ini membutuhkan sumbangsih dari generasi ke generasi untuk kembali menghidupkan kesenian yang sempat redup karena beberapa faktor penghambat. Dari keterangan masyarakat, faktor lain yang sangat berpengaruh adalah permasalahan tentang media promosi atau pemasaran kesenian yang kurang dikuasai oleh warga. Kurangnya media promosi dan cara promosi yang tidak dikemas secara menarik dan meluas,menyebabkan pertunjukkan yang mengangkat tema kesenian tidak banyak diketahui olehmasyarakat. Padahal masyarakat butuh sebuah mediator yang menghubungkan mereka dengan suatu acara-acara.

\section{Metode Penyelesaian Masalah}

Berdasarkan analisis, permasalahan yang dihadapi oleh sebagian besar masyarakat Desa Jurang Blimbing Kelurahan Tembalang, Kecamatan Tembalang Kota Semarang yaitu Kurangnya pengembangan media promosi dan optimalisasi Dokumentasi dalam pemasaran kesenian lokalnya, Maka kegiatan Kuliah Kerja Nyata sebagian difokuskan pada perihal Perencanaan, Pemahaman, Proses Rancangan Implementasi serta hasil Dokumentasi Kesenian dalam upaya memberikan inovasi pada pagelaran ataupun pementasan kesenian yang ada di dalamnya sesuai dengan kebutuhan yang ada. Dari sini adanya suatu acara pertunjukkan merupakan strategi yang paling baik dilakukan sebagai langkah awal memperkenalkan 
kembali macam-macam kesenian jawa. Generasi muda sekarang banyak berpikir kalau seni kethoprak itu sekarang sangat tidak menarik bila dibandingkan dengan seni modern padahal berubahnya jaman, kesenian tradisional yang sekarang pun berubah kemasan menjadi lebih menarik dan tidak membosankan seperti yang mereka pikir. Maka dari itu, promosi kali ini sekaligus ingin memperlihatkan pencitraan seni yang semangat, ceria, anggun, dan banyak macamnya.

Mengangkat suatu event dari Kethoprak dimana masih dipegang oleh warga Desa Jurang Blimbing merupakan suatu kebanggaan tersendiri karena sekaligus membantu mereka menunjukkan kepada masyarakat bahwa masih ada anak muda yang peduli terhadap keberadaan seni ini yang sudah menurun dari waktu ke waktu sehingga muda-mudi lain diluar sana ikut tergerak bermula dari mengenal seni itu sendiri dan gol terbesarnya mereka ikut berperan aktif untuk mencintai dan merawat keberadaan kesenian tradisional.Media promosi secara tidak langsung sudah berperan ikut memperkenalkan ragam Seni Jawa dari berbagai foto-foto yang dipakai, tetapi bila sebagain masih menilai kalau media promosi hanya membantu proses mengenalkan acara tersebut maka, ditambah duamedia yang berperan lebih aktif dan menonjol untuk memperkenalkankesenian tradisional yang bisa diakses setiap waktu dan buku sebagai media yang bisa bertahan lama. Serta adanya desain booth di tempat acara dimana masyarakat bisa masuk dan melihat bahkan mencoba langsung menggunakan alat-alat musik.

Fokus utama Faktor Utama Pelestarian kesenian tradisional sebagai upaya dalam menumbuhkan kecintaan Budaya Lokal di masyarakat Jurang Blimbing Tembalang tersebut meliputi beberapa aspek dapat dijelaskan sebagai berikut :

1. Seni Sebagai Identitas Lokal,

2. Dokumentasi sebagai wadah Pelestarian,

3. Rancangan Pelestarian Kesenian melalui Kemasan Multimedia,

4. Proses Implementasi Rancangan Pelestarian,

5. Budaya Lokal.

\section{Hasil dan Pembahasan}

Seni adalah segala sesuatu yang diciptakan oleh manusia yang mengandung unsur keindahan dan mampu membangkitkan perasaan dirinya sendiri maupun orang lain. Berdasarkan definisi ini seni adalah produk keindahan, di mana manusia berusaha menciptakan sesuatu yang indah dan dapat membawa kesenangan. Istilah seni berasal dari bahasa "sanskerta" yaitu sani yang diartikan pemujaan, persembahan dan pelayanan yang erat dengan upacara keagamaan yang disebut kesenian. Seni juga merupakan Identitas 
lokal dari sebuah daerah yang dapat menunjang perkembangan masyarakat dari berbagai bidang. Sebagai salah satu identitas yang menunjukkan sebagaimana daerah tersebut dipandang oleh masyarakat daerah lain, seni tentu saja membutuhkan pemasaran dan promosi agar tetap terjaga kelestariannya. Salah satunya melalui dokumentasi.

Dokumentasi sebagai wadah Pelestarian Kesenian memegang pernan penting di dalam Desa Tematik Seni dan Budaya. Pendokumentasian ini dapat menunjang berbagai segi yang dapat digunakan untuk menghidupkan kembali seni yang telah terlahir sebelumnya namun sempat redup. Dapat disimpulkan dokumentasi sendiri berarti kumpulan dari berbagai dokumen dapat memberikan keterangan ataupun bukti yang berkaitan dengan proses pengumpulan serta pengelolaan dokumen secara sistematis dan menyebar luaskan kepada pemakai informasi tersebut, atau bisa juga disimpulkan dokumentasi adalah suatu pekerjaan yang bertugas mengumpulkan, menyusun, mencari, menyelidiki, meneliti, dan mengolah serta memelihara dan juga menyiapkan sehingga menjadi dokumen baru yang bermanfaat. Dapat berupa foto, video, karya cetak, karya rekam dan audio visual. Kesenian desa jurang blimbing beraneka ragam, salah satunya : kaligrafi, rebana, kuda lumping, kerajinan tangan dan ketoprak. Dalam melestarikan kesenian dapat dilakukan dengan cara :

\section{Culture Experience}

Cara ini adalah dengan cara kita terjun langsung untuk mempelajari budaya masing-masing daerah sesuai daerahnya. Contoh suku sunda mempelajari tari jaipong atau pencak silat. Hal ini penting untuk dipelajari dari generasi ke kegenari agar tetap lestari sehingga kita dapat memperkenalkan sekaligus mempertontonkan budaya kepada orang banyak bahkan pada dunia.

\section{Culture Knowledge}

Cara ini yaitu dengan membuat pusat informasi kebudayaan masing-masing, sehingga setiap orang dapat dengan mudah untuk menemukan informasi tentang suatu kebudayaan suatu daerah. Di era modern sekarang ini situs website bisa menjadi alternatif yang mudah untuk dijadikan sarana menyediakan segalan sumber informasi tersebut.

Peran dokumentasi dalam pelestarian dapat melalui pengumpulan, pengklasifikasian dan meneruskan menyebarluaskan dokumen-dokumen kepada yang membutuhkan. Perlu diketahui, bahwa dokumentasi merupakan sumber informasi. Masyarakat jurang blimbing yang notabene masyarakat seni dapat mengenalkan budaya keseniannya ke seluruh masyarakat indonesia dengan cara mendokumentasikan hasil dari kesenian yang ada di desa jurang blimbing. Keuntungan masyarakat menyebarluaskan hasil dokumentasi ke seluruh negeri yaitu, desa jurang blimbing dapat dikenal seluruh indonesia, potensi seninya dapat berkembang karena banyak masyarakat luar yang tertarik untuk datang di kampung seni jurang blimbing. Sehingga dapat ditarik kesimpulan, dokumentasi sebagai media pelestarian merupakan proses pendokumentasian sebuah karya maupun kesenian, dapat memberi kesan tersendiri bagi para aktor seni 
tersebut. Masyarakat jurang blimbing dapat memiliki kenang-kenangan berupa foto maupun video yang berisi kesenian ketoprak, kuda lumping dan kaligrafi. Dalam proses dokumentasi dapat dikatakan sebagai media untuk pelestarian kesenian, media rekam yang dapat menghasilkan sebuah karya cetak maupun video sebagai bukti otentik yang dapat di sebar luaskan kepada masyarakat seluruh indonesia untuk memberikan sebuah informasi tentang desa kecil yang memiliki potensi kesenian yang luar biasa.

Desa Jurang Belimbing Tembalang Semarang merupakan salah satu Desa di wilayah Kota Semarang Jawa Tengah yang memiliki seni budaya dan kearifan lokal menarik. Desa Jurang Belimbing Tembalang Semarang juga terkenal dengan Desa Tematik Seni yang terdiri dari kesenian kethoprak, kaligrafi, karawitan dan kuda lumping. Namun, pertunjukan seni budaya di Desa Jurang Belimbing Tembalang saat ini mengalami pasang surut dibanding dengan jaman dahulu yang mana masyarakat berantusias ikut terjun dalam pertunjukan terutama pada kesenian kethoprak sehingga hal ini merupakan penghambat dari kurang adanya identitas seni buda di desa tersebut.

Mempertahankan sesuatu yang sifatnya tradisional dan kuno sangat sulit untuk jaman sekarang ini. Seperti halnya dengan kesenian yang ada di Desa Jurang Belimbing Tembalang Semarang, dimana anak mudanya kurang tertarik dengan kesenian yang ada seperti kethoprak, kaligrafi dan kuda lumping. Dengan permasalahan ini, Desa Jurang Belimbing Tembalang Semarang yang terkenal dengan keseniannya lebih memilih untuk berdiri sendiri dan tidak memperhatikan faktor-faktor penghambat dalam melestariannya. Cara supaya tetap melestarikan kebudayaan dan kesenian yang ada, masyarakat Desa Jurang Belimbing Tembalang memiliki agenda rutin latihan yang bisa diikuti oleh masyarakat sekitar. Agenda rutin latihan tersebut berupa latihan karawitan yang dilakukan setiap hari sabtu dipanggung terbuka, latihan kuda lumping di RT 2, latihan kethoprak, dan untuk latihan kaligrafi masyarakat bisa langsung datang ke tempat pakar kaligrafinya. Adanya agenda rutin ini mampu membuktkan eksistensi mereka untuk mempertahankan kesenian di Desa Jurang Belimbing Tembalang Semarang.

Menjadikan Desa Jurang Belimbing Tembalang Semarang sebagai identitas Desa Seni yaitu dengan salah satu cara disalurkannya jiwa seni kepada masyarakat sekitar untuk ikut berpartisipasi dan mendukung kemajuan desa. Identitas seni budaya di Desa Jurang Belimbing Tembalang Semarang terbentuk melalui proses yang tidak mudah dan tentunya meneruskan dari orang-orang dahulu yang tinggal di desa tersebut. Penandaan identitas dapat dilihat pada kebiasaan masyarakat yang selalu membuat dan melaksanakan agenda kegiatan seni budaya. Komponen-komponen yang melekat pada Desa Jurang Belimbing Tembalang Semarang itulah yang mengangkat adanya identitas Desa Tematik Seni supaya tetap berpotensi.

Sekarang ini informasi tentang apapun menjadi sangat mudah diakses oleh banyak masyarakat. Hal ini merupakan akibat dari adanya penemuan dan aplikasi bentuk media yang menggunakan alat komunikasi serta kemajuan teknologi yang ada. Pengoptimalan promosi seni budaya dan kearifan lokal di Desa Jurang 
Belimbing Tembalang Semarang dalam bentuk pendokumentasian dapat bermanfaat sebagai representasi dan pencitraan wilayah dan budaya masyarakat sekitar.

Aset seni budaya dan kearifan lokal berupa dokumen merupakan hal penting supaya bisa dijadikan bahan yang menjadi ciri khas pada Desa Jurang Belimbing Tembalang Semarang untuk mengeksplorasi potensi wilayah tersebut. Beragam seni budaya dan kearifan di wilayah Desa Jurang Belimbing Tembalang meliputi Kethoprak Srimulyo, kuda lumping, kaligrafi, dan karawitan. Mengoptimalkan dengan cara mendokumentasikan kegiatan seni budaya dan kearifan lokal bisa dijadikan sebagai strategi promosi dan pencitraan sosial budaya bahwa di Indonesia memiliki banyak kesenian dan kebudayaan. Promosi seni budaya dan kearifan lokal bisa melalui dokumentasi-dokumentasi berupa foto, film dokumenter, video dokumenter, dan lain-lain. Manfaat dari adanya pendokumentasian untuk kegiatan promosi yaitu supaya masyarakat terutama di wilayah Kota Semarang mampu mengenal bahwa Desa Jurang Belimbing Tembalang Semarang memiliki potensi seni yang sangat baik dan harus didukung. Menunjang nilai dan melestarikan budaya agar tidak punah. Dengan mendokumentasikan acara yang diselenggarakan misalnya yaitu hari ulang tahun kuda lumping yang diperingati dengan pertunjukan kuda lumping, pementasan kethoprak, dan lain-lain.

Dalam perancangan objek Pusat Kesenian di kampung seni jurang belimbing, kita dapat merancang dari fungsi, tempat kesenian, dan merancang kesenian itu sendiri. Rancangan Pelestarian Kesenian melalui Kemasan Multimedia dapat dijadikan sebagai salah satu solusi konkrit. Objek rancang kampung seni desa jurang belimbing memiliki fungsi edukatif, komunikatif, artistik, dan rekreatif dengan jenis pertunjukan yang ditampilkan adalah seni pertunjukan dan pagelaran. Dimana berfungsi sebagai media ekspresi, media apresiasi, media komunikasi, dan sarana pengembangan bakat. Fasilitas yang disediakan untuk memenuhi fungsi tersebut adalah panggung dengan tingkatan-tingkatan tempat duduk tidak beratap dan berbentuk arena (untuk kegiatan pertunjukan terbuka yang populer diadakan yaitu kesenian ketoprak "Sri Mulyo", Kuda Lumping 'Turangga Tunggak Semi', dan Kaligrafi 'Nil Nal Muna'.Selain itu, juga fasilitas auditorium untuk pemenuhan fungsi pertunjukan yang bersifat tertutup (untuk kegiatan pertunjukan yang membutuhkan backdrop dan pengaturan pencahayaan, penghawaan, dan gamelan).

Estetika merupakan unsur penting dalam panggung terbuka untuk penampilan kesenian Pada objek rancang kampung seni jurang belimbing, estetika muncul dari perencanaan yang saling terintegrasi antara ruang, bentuk, dan struktur. Dari perencanaan tersebut dihasilkan tatanan massa bangunan yang simetris, terkait tujuan objek rancang Pusat Kampung seni desa jurang belimbing menegaskan kembali identitas kota dengan menjadikan bangunan utama pada kawasan rancangan sebagai landmark dan kesatuan dengan lingkungan sekitar lahan. Landmark mempermudah manusia dalam mengenali tempat berpijak. Selain digunakan untuk penanda kawasan, keberadaan landmark sering digunakan sebagai hirarki suatu wilayah, penunjuk arahdan pembentuk skyline Selain pada tatanan massa bangunan, bentuk bangunan juga menampilkan kesan ekspresif sesuai dengan tema yang diangkat. Bentuk terinspirasi dari mahkota penari yang menunjukkan salah satu ekspresi seni yang mampu memberikan impresif kepada penonton. 
Proses Implementasi Rancangan Pelestarian ini dapat dimulai dari berbagai elemen di masyarakat untuk diajak pro aktif mendukung upaya pelestarian dengan pengoptimalan media dokumentasi kesenian. Mulai dari cara mengolah dengan manual maupun software digital, memproses dan mempresentasikan hasil dokumentasi dengan berbagai bentuk yang diolah kemudian memasarkan ke masyarakat umum di daerah Jurang Blimbing pada khususnya dan Semarang pada umumnya. Implementasi di dalam masyarakat ini dapat tergerak dengan adanya masyarakat dan dukungan penuh dari Pejabat Desa setempat serta Pemerintah daerah setempat.

Inovasi dalam pelestarian kesenian di desa jurang belimbing tembalang sudah sedikit mengalami perkembangan, karena beberapa kesenian sudah di lestarikan dan di pasarkan melalui media online. Seperti, Kaligrafi yang di pasarkan melalui internet, dan kuda lumping yang sudah di lestarikan di media sosial you tube. Namun, masih banyak permasalahan dalam kesenian ketoprak. Pasalnya ketoprak membutuhkan banyak sekali biaya jadi ketoprak di desa jurang belimbing saat ini masih enggan untuk bangun dan susah untuk melestarikan ketoptak tersebut. Inovasi lain dapat di Implementasikan memalui kemasan multimedia sebagai akses ke semua pihak, baik masyarakat Desa Jurang Blimbing asli dengan masyarakat umum diluar Jurang Blimbing yang dapat mengenal Kesenian dan Kebudayaan apa saja yang terdapat di dalam Desa Temtik Seni dan Budaya tersebut. Selain ajang Promosi dan Pemasaran, Inovasi ini akan berpengaruh pada kemajuan dan pelestarian kesenian yang sempat redup beberapa waktu terakhir ini serta menunjang minat masyarakat dalam memajukan seni daerah sendiri untuk mengatasi berbagai kendala yang dihadapi selama ini.

Menumbuhkan dan melestarikan kesenian tradisional sangat penting untuk meningkatkan kecintaan terhadap budaya lokal. Masyarakat jurang blimbing atas bimbingan dan pendampingan dari mahasiswa KKN sudah mulai nampak usaha menumbuhkan kesenian tradisonal setempat. Ditambah dukungan dari pemerintah daerah setempat untuk menjadikan desa jurang blimbing sebagai desa seni, yang nantinya akan dapat meningkatkan taraf hidup masyarakat setempat. Secara tidak langsung dengan dikenalnya jurang blimbing sebagai desa seni akan menarik masyarakat lain untuk mengunjungi sehingga bisa menambah pendapatan desa. Dengan melestarikan kesenian daerah juga akan menanamkan nilai-nilai kecintaan pada budaya lokal terhadap generasi muda di masyarakat jurang blimbing.

\section{Kesimpulan dan Saran}

Pemikiran mengenai Pelestarian kesenian tradisional sebagai upaya dalam menumbuhkan kecintaan Budaya Lokal di masyarakat Jurang Blimbing Tembalang muncul karena masyarakat Desa Tematik Seni dan Budaya Jurang Blimbing memiliki permasalahan terkait pemasaran kesenian, promosi serta kurangnya minat pelestarian kesenian yang ada di dalamnya. Pelestarian kesenian tradisional sebagai upaya dalam menumbuhkan kecintaan Budaya Lokal di masyarakat Jurang Blimbing Tembalang akan 
berpengaruh pada kemajuan dan pelestarian kesenian yang sempat redup beberapa waktu terakhir ini serta menunjang minat masyarakat dalam memajukan seni daerah sendiri.

Bentuk dari Pelestarian kesenian tradisional sebagai upaya dalam menumbuhkan kecintaan Budaya Lokal di masyarakat Jurang Blimbing Tembalang ini dapat dimulai dari berbagai elemen di masyarakat untuk diajak pro aktif mendukung upaya pelestarian dengan pengoptimalan media dokumentasi kesenian. Mulai dari cara mengolah dengan manual maupun software digital, memproses dan mempresentasikan hasil dokumentasi dengan berbagai bentuk yang diolah kemudian memasarkan ke masyarakat umum. Inovasi lain dapat di Implementasikan memalui kemasan multimedia sebagai akses ke semua pihak. Untuk mewujudkan sebuah Desa Tematik Seni dan Budaya Pengetahuan dan Pelestarian kesenian tradisional sebagai upaya dalam menumbuhkan kecintaan Budaya Lokal di masyarakat Jurang Blimbing Tembalang sangat dibutuhkan dalam menyongsong kembali potensi kesenian lokal sebagai identitas masyarakat setempat. Maka dari itu, Tindak lanjut dari Inovasi dalam pengoptimalan dokumentasi sebagai media promosi penunjang pelestarian seni dan budaya ini akan berhasil di dalam masyarakat apabila masyarakat tergerak dan mendapatkan dukungan penuh dari Pejabat Desa setempat serta Pemerintah daerah setempat untuk bersama-sama menyongsong Desa Tematik Seni dan Budaya di Jurang Blimbing, Kelurahan Tembalang, Kecamatan Tembalang Kota Semarang.

\section{Daftar Pustaka}

Artikelsiana. (September, 2015). Pengertian Seni Fungsi Macam-macam seni. Diperoleh 31 Januari 2018. dari http://www.artikelsiana.com/2015/09/pengertian-seni-fungsi-macam-macam-seni.html

Oka, A. Yoeti. 1985. Melestarikan Seni Budaya Tradisional yang Nyaris Punah.Jakarta: Proyek Penulisan dan Penerbitan buku/majalah pengetahuan umum dan profesi Departemen Pendidikan dan Kebudayaan.

Heri Wijayanto. 2008. Inovasi Ganongan pada Kesenian Reog Ponorogo melalui Kegiatan Magang Kewirausahaan. Ponorogo : Universitas Muhammadiyah Ponorogo.

Muchamad Chayrul Umam. 2014. Upaya Pelestarian Kesenian Kenanthi di Dusun Singosaro, Desa Sidoagung, Kecamatan Tempuran, Kabupaten Magelang. Fakutas Ilmu Sosial. Universitas Negeri Yogyakarta.

"Pengertian Seni, Fungsi Seni, dan Jenis-jenis Seni". di akses pada : http://www.ilmusahid.com/2016/08/pengertian-seni-fungsi-seni-dan-jenis.html 31 januari 2018 pukul : 23.17 